\section{Ujevne historier fra røykekulturen}

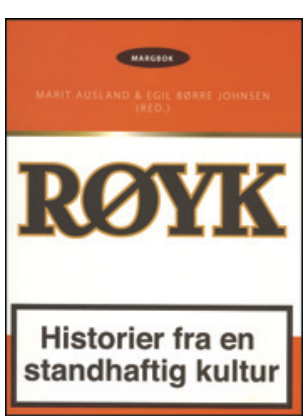

Marit Ausland, Egil Børre Johnsen, red.

Røyk

Historier fra en standhaftig kultur. 158 s, ill.

Tromsø: Margbok forlag, 2013.

Pris NOK 268

ISBN 978-82-93065-30-2

Dette er åpenbart ingen lærebok, men inneholder ifølge forordet tekster som forsvarer retten til å velge livsstil. Det er drøyt 20 korte kapitler fra omtrent like mange kjente og ukjente norske bidragsytere. Kapitlene er inndelt i seks temaer, bl.a. Vår historie, Vår glede, Vår filosofi og Vår stolthet.

Layouten er preget av nærmere 50 (ofte helsides) gamle reklameoppslag for tobakk og en rekke småbilder, de fleste med god oppløsning.

Den økende fordømmingen av røyking fra samfunnet og nymoralismen får stor plass. Reklameforbudet, prispolitikken, røykebuene, røykeloven fra 2004, Tostrupkjellerens forvandling og Høybråten får gjennomgå, likeså helseadvarslene på tobakkspakkene. Militante røykemotstandere får sitt pass påskrevet, og i samme slengen nevnes like godt Adolf Hitlers røykemotstand.

Her beskrives typiske røykeopplevelser, og det gis ærlige fortellinger om røykestopp, abstinenser og ubehag og om befrielsen med å begynne å røyke igjen. Den umiddelbare effekten av et magedrag omtales poetisk og omsorgsfullt. Flere tekster dveler også ved mange røykeres ambivalens: at man vil fortsette samtidig som man vil slutte.

Flere kjendiser/forfattere bidrar. Dag Solstad omtaler røykeloven som vulgær, og som «tidenes hysteri». Knut Nærum gir et beskjedent bidrag, og Thomas Hylland Eriksen reflekterer over «urovekkende skrekkpropaganda om røyking», dog med et kunnskapsgrunnlag som må oppfattes som sviktende. Knut Husum beskriver flere dyktige røykende kirurger og krigskirurger. Historien om sir Walter Raleigh, opphavsmannen til de moderne røykevanene i Europa på 1500-tallet, har mange ingredienser. Mens noen leger på den tiden er opptatt av røykingens barbariserende effekter, omtalt som «nicotinismus mentalis», ser andre leger tobakk som et vidundermiddel og universalmedisin.

Helhetsinntrykket er nokså stykkevis og delt. Her finnes enkelte gode tekster og god lesning, men flere bidrag er mer preget av kampen for selvrespekten som røyker - hvor aggresjonen blir projisert på samfunnets håndtering av røyking mer enn på egen avhengighet. I det hele tatt problematiseres tobakksavhengigheten som sådan i liten grad. Jeg hadde håpet på ærlige, innsiktsfulle tekster som nettopp beskrev forståelsen av egen nikotinavhengighet på en god måte.

Boken er på ingen måte obligatorisk, men kan være nyttig og tidvis morsom for enhver som ønsker økt innsikt i tobakkens historie, røykeres polemikk, retorikk, psykologi og typiske forsvar for egen vane.

Frode Gallefoss

Forskningssjef

Sørlandet sykehus, Kristiansand

\section{Historie eller historieforvrengning?}

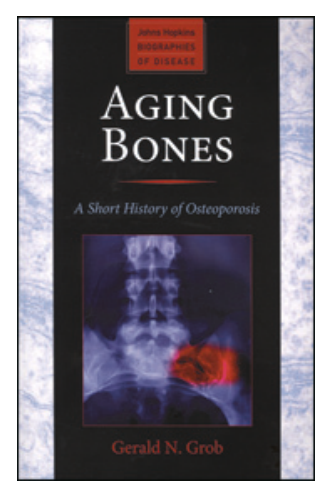

\section{Gerald N. Grob \\ Aging bones}

A short history of osteoporosis. $284 \mathrm{~s}$

Baltimore, MD: The Johns Hopkins University Press, 2014. Pris USD 25

ISBN 978-1-4214-1318-1

Forfatteren er historiker og gir et historisk blikk på hvordan osteoporose, som tidligere ble oppfattet som et aldringsfenomen, nå anses som sykdom.

Beretningen om kvinnesyn, overgangsalder, aldring og østrogen er tankevekkende. Resten av boken er preget av forfatterens personlige holdninger. Han mener at medisinfaget er markedsstyrt og at utprøvninger av medisiner ikke er til å stole på fordi industrien betaler. Han hevder at negative funn fra medikamentutprøvninger i liten grad publiseres, uten å eksemplifisere eller dokumentere påstanden. Kontrollerbarheten som preger dagens utprøvninger beskrives ikke. Han nevner heller ikke de medikamentene som er utprøvd, men som aldri er blitt markedsført på grunn av negative resultater, og reflekterer ikke over hvem som da tar det økonomiske tapet. Men at selgere av apparater til å måle osteoporose tar snarveier, kan imidlertid ikke underslås. Forfatteren hevder videre at osteoporose vil forsvinne som andre «motesykdommer», men nevner ikke det naturvitenskapelige grunnlaget som nå foreligger.

Et par viktige forhold er vel verdt å legge merke til: hvordan medikamentprodusentene sponser organisasjoner, forskere og andre som påvirker markedet, dels ved grovt å overdrive konsekvensene av brudd (kanskje i det godes hensikt), og beskrivelsen av hvilken innflytelse fremtredende politikere kan ha.

Det er nyttig å lese hvordan man utenfor det medisinske fagområdet oppfatter faget vårt, men våre uklarheter har gitt forfatteren flere billige poenger: Vi trekker med oss et gammelt begrep, osteoporose, men mener å uttrykke noe nytt. Ofte skiller vi ikke mellom sykdom og risikofaktor, heller ikke bruker vi ord som skiller mellom skjelettets materielle og strukturelle egenskaper. Vi forvirrer oss selv og andre ved å bruke uttrykket beintetthet om noe som ikke er tetthet. Gjennomgang av litteratur også fra andre «utenfor» burde anspore oss til klarhet.

Jeg savner bidrag fra forskjellige fagpersoner. For eksempel mangler omtale av (bio)mekanikk, som er avgjørende for den siste tids oppfatninger. Likeledes kunne vår (mis)bruk av statistikk vært gjenstand for en grundig og kritisk vurdering. Forfatteren bruker bruddrisikokalkulatoren FRAX der det passer ham, men overser argumentene mot FRAX.

Boken illustrerer den forvirring som preger fagområdet, med raske endringer i ekspertoppfatninger og anbefalinger, men den er langdryg. Systematisering, gjerne tabellarisk, hadde vært mulig.

Jeg tror neppe boken er for dem som vil ha praktisk nyttig og objektiv informasjon.

\section{Arne Høiseth}

Medisinsk ansvarlig radiolog, Curato Røntgeninstitutt Oslo City

Oppgitte interessekonflikter: Anmelder er ansatt i Curato Røntgen som utfører beinmassemålinger med DXA-teknikk. Han har deltatt i internasjonale medikamentutprøvninger for firmaet Amgen som ansvarlig «principal investigator» og vært medforfatter i rapporter. 